\title{
Hva er seksuell helse?
}

\section{Seksualitet er et primærbehov og har stor betydning for et menneskes livskvalitet gjennom hele livet.}

\section{Haakon Aars}

Lege

Institutt for klinisk sexologi og terapi, Oslo

Psykisk helse

Seksualitet

Sykepleien 2021109 (83165) (e-83165)

DOI: 10.4220/Sykepleiens.2021.83165

\section{Hovedbudskap}

Hvem eier seksualiteten, hva påvirker den, og hvilke myter og tabuer finnes fortsatt? Artikkelen reflekterer over kjønn og seksuell helse og viser hvordan seksualiteten kommer til uttrykk i ulike aldersgrupper og kulturer.

Vår fantastiske seksualitet berører alle planene av vår menneskelige eksistens og er en kilde til god livskvalitet, nytelse og glede.

Seksualiteten angår alle mennesker, uansett alder og livssituasjon. Den griper dypt inn i våre psykiske, fysiske, kulturelle, sosiale og åndelige sider ved det å være menneske.

Det er en nær sammenheng mellom livskvaliteten vår og hvordan vi fungerer seksuelt. Et godt seksualliv betyr mye for velværet, en god psykisk helse og gode relasjoner til menneskene rundt oss. 
Dette har jeg også erfart i mitt langvarige arbeid med enkeltmennesker og par, mennesker med ulike seksuelle tiltrekninger og i forskjellige parrelasjoner, med et mangfold av sykdommer, funksjonsnedsettelser og funksjonshemninger.

\section{Hva er seksualitet?}

Ordet «seksualitet» omfatter så mye mer enn det vi vanligvis tenker på når vi snakker om sex. I tillegg til det rent fysiske med kroppslige funksjoner og det sex innebærer av nytelse og orgasme, omfavner seksualiteten også samlivet vårt med en kjæreste, fantasier, kroppslig og mental opplevelse av nærhet, intimitet og kroppen som følelsesorgan og dens erogene soner. Alt dette bidrar til og avgjør vår seksuelle helse.

Konsekvenser av hendelser, plager, sykdom og lidelser påvirker og setter begrensninger for vår fysiske, mentale og sosiale helse. De griper også inn i seksualiteten og påvirker den seksuelle helsen vår.

Verdens helseorganisasjon (1) sier at den seksuelle helsen er en integrert del i ethvert menneskes personlighet. Seksualiteten er et av grunnbehovene til mennesket og et aspekt ved det å være menneske som ikke kan atskilles fra andre livsaspekter.

\section{Hvem eier seksualiteten?}

Min seksualitet er min egen. Den er en sentral del av meg som individ, en drift til å søke nærhet til meg selv og til å finne nærhet og kjærlighet til en annen person.

Seksualiteten uttrykkes gjennom det vi føler. Den kommer til uttrykk gjennom hvordan vi berører og berøres av andre; den er til stede og er en vesentlig del av samspillet vårt med andre mennesker innenfor alle områder. 
Seksualiteten vår er også påvirket av samfunnet rundt oss, av kulturen og omgivelsene vi lever i. Til alle tider og $i$ alle kulturer er seksualiteten avhengig av og påvirket av ideologier og religioner, og av den politikken som råder.

I dagens virkelighet er det dessverre fortsatt enkelt å finne grove eksempler på hvordan regimer bryter menneskerettigheter og benytter seksualiteten som et middel i sin maktkamp - det være seg religiøse samfunn og institusjoner så vel som politiske.

Velkjente eksempler i en rekke land er avstraffing av kvinner som kjemper for seksuell frihet, forfølgelse av homofile som nektes rettigheter til å elske en av samme kjønn, eller andre minoriteter som ikke får eie og leve ut sin egen kjønnsidentitet.

\section{Det er færre forskjeller mellom kjønnene}

Kvinner og menn har mye til felles når det gjelder sex, men det er også forskjeller på hva menn og kvinner er seksuelt opptatt av, hva de liker, og hvordan de nærmer seg hverandre. Likevel er min erfaring at forskjellene mellom kjønnene faktisk er færre enn likhetene (2).

Mye har skjedd med åpenheten om kvinners seksualitet siden kvinnefrigjøringen for alvor satte inn i 1970-årene. Selv om kvinnekampen har satt synlige spor særlig i vår del av verden, ser vi tydelig en bevegelse i synet på kvinner også mange andre steder i verden, der kvinners seksuelle helse og rettigheter stadig oftere kommer på dagsordenen.

\section{«Fortsatt eksisterer ideen om at menn har lyst på sex hele tiden.»}


Det er tross alt ikke så mange tiårene siden normene krevde at en kvinne skulle sitte pent og vente på at han, den rette, skulle komme og varte henne opp. Kvinner som på en eller annen måte viste at de hadde lyst på sex, ble gjerne fort betegnet som «nymfomane» i negativ forstand.

Hvis menn, derimot, var pågående med stor seksuell appetitt, ble de ansett som riktige menn og positivt betegnet som normalt «kåte».

Selv i dag kan vi vel ikke helt befri samfunnet fra myten om kvinner som hore eller madonna, etter som de har lyst på sex eller ikke. På samme måte eksisterer fortsatt ideen om at menn har lyst på sex hele tiden.

\section{Vi er blitt mer åpne om homoseksualitet}

Også åpenheten om homoseksualitet er endret hos oss. Det samme er slett ikke tilfellet i store deler av verden, selv i noen europeiske land. Åpenhet og tilkjempede rettigheter kan derfor ikke tas for gitt.

Både norske og internasjonale unders $\varnothing$ kelser viser at 3-5 prosent av den voksne befolkningen har en seksuell orientering som i all vesentlig grad retter seg mot en av samme kjønn (3). Altså som har en homoseksuell orientering.

Biseksuelle personer blir seksuelt tiltrukket av både menn og kvinner. I Norge ble homofili først avskaffet som sykdomsdiagnose i 1979. Lov om registrert partnerskap ble innført i 1993, og felles ekteskapslov kom i 2009.

\section{Flørting er godt for den seksuelle helsen}

Gjennom de siste generasjonene er synet på kvinners seksuelle helse revolusjonert: Det er akseptert at kvinner har lyst på sex, og det er lov å si «nei» uten å bli sett på som «frigid» - et begrep som typisk nok aldri fantes for menn. Kvinner kjenner sine seksuelle $\varnothing$ nsker, vet hva de ønsker av sine sexpartnere, og tar seksuelle initiativer - og får aksept for det. 
At menn liker å kurtisere og varte opp, og kanskje være litt pågående, gi komplimenter og komme med gaver og overraskelser, er ikke en motsetning til kvinners selvstendighet. Det samme gjelder selvsagt om en kvinne oppvarter en kvinne eller en mann flørter med en mann.

Det er ikke bare lov, men også godt for den seksuelle helsen å ta imot gaver og komplimenter, og bli flørtet med. Også for oppvarteren er det god helse i å kunne flørte og «by seg frem» og få respons på seg selv som sexpartner. En slik type sexspill handler ikke om å konservere eller å falle tilbake til gamle kjønnsrollemønstre.

\section{Seksualitet forbindes med lyst}

De vanligste seksuelle problemene kvinner presenterer, er knyttet til seksuell lyst, orgasmeproblemer og smertetilstander ved samleie: dyspareunier. Menns vanligste problemer er knyttet til for tidlig sædavgang, andre utløsnings- og ereksjonsproblemer og tap av seksuell lyst.

Generelt sett kan seksualiteten i dag sies å være mer knyttet til lyst og glede enn før. Ikke minst er tryggheten betydningsfull for behandling av sykdommer, prevensjon og kvinners selvbestemmelse over egen kropp, som å kunne velge abort.

\section{«Seksualiteten i dag kan sies å være mer knyttet til lyst og glede enn før.»}

En kvinne behøver ikke være redd for uønsket graviditet, noe som også påvirker menns seksuelle helse. Rettigheter er lovfestet, og flere tabuer har tapt sin kraft - for eksempel tabuer om lesbisk og homofil seksualitet, transkjønnet identitet og behandling av seksuelle plager og sykdommer.

Alle er viktige bidrag til å bedre den seksuelle livskvaliteten, uavhengig av kjønnsidentitet og seksuell preferanse. 


\section{Hva påvirker barns og unges seksuelle helse?}

Mange unge i dag tør ikke dusje sammen med andre. En ny form for bluferdighet har nådd dem. Men også en redsel for å bli tatt bilde av - bilder som så kan slippes på nettet og være tilgjengelig for hvem som helst.

Også alt unge utsettes for, påvirker holdningen deres til kroppsbilde og naturlig nakenhet, ikke minst gjennom reklame og pornoindustrien om hvordan en kropp «skal» se ut for å være akseptabel og seksuelt attraktiv.

Skam over egen kropp bidrar til dårlig selvfølelse og påvirker den seksuelle helsen. Det oppstår ubalanse mellom behovet for seksualitet og lysten på sex og det å ikke tørre, føle seg utilstrekkelig og ikke være attraktiv nok.

Små barn begynner naturlig å bli kjent med sin egen kropp gradvis. Som ledd i utviklingen får de etter hvert også en kjønnsidentitet og interesse for å unders $\varnothing$ ke andre barns kjønn og kropper (4).

Aasland påpeker at barna ikke må hindres i å leke eller utforske sin egen og venners kropper og kjønnsorganer eller leke det voksne gjerne kaller «seksuelle leker»: sexing-, doktor-, rumpe- og mor-far-barn-leker.

Små barn har ingen begreper for eller tanker om sex. Lekene og utforskingen er sider ved barnas utvikling.

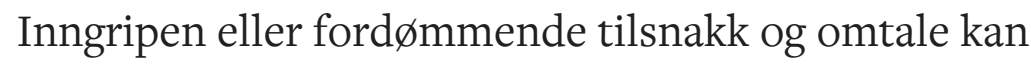
påvirke barnas utvikling og seksuelle helse (4).

Hvordan små barn oppfatter og lærer om sex og holdninger til seksualitet, skapes av og er prisgitt barnets omgivelser og betydningsfulle omsorgspersoner (4). Grunnlaget for personens seksuelle helse senere i livet legges tidlig $\mathrm{i}$ barneårene (5). 


\section{Eldres seksuelle helse er mer kompleks}

Vi blir eldre i dag enn tidligere. Dagens eldre har en mer aksepterende og aktiv holdning til seksualitet, seksuelle behov og sin seksuelle helse enn tidligere generasjoner (6).

Med alderen dukker det gjerne opp flere lidelser, og helsebildet blir mer sammensatt enn hos yngre mennesker. Minkende seksuell lyst er en utfordring som $\varnothing$ ker med alderen og henger sammen med mindre produksjon av testosteron, et hormon som i vesentlig grad styrer den seksuelle lysten både hos menn og kvinner.

Sykdom og medikamenter påvirker seksualiteten, og eldre bruker ofte flere medikamenter samtidig. Bildet på eldres seksuelle helse blir dermed komplekst.

Norge er ansett som et land med en seksuelt liberal kultur og like rettigheter for alle. Likevel har både helsepersonell, eldre og deres familie en tendens til bare å snakke om fysiske symptomer.

\section{Eldres seksualitet er fortsatt tabu}

De fleste er uvante med å gi uttrykk for følelser og bearbeide følelsesmessige belastninger og tar ikke opp problemer knyttet til følelser eller seksualitet. Mange seksuelle problemer blir derfor ofte ikke behandlet ordentlig.

Eldre, men også helsepersonell, har ikke tilstrekkelig kunnskap om seksualitet og bærer på holdninger som ikke akkurat fremmer kommunikasjonen om seksuell helse.

Schaller og medarbeidere (6) dokumenterer at helsepersonell ofte sliter med en følelse av pinlighet og skam når de får spørsmål om seksualitet, og mangler kunnskap og forståelse om temaet. De sier videre at eldre selv sliter med selvoppfyllende profetier om egne fordommer og negative holdninger til at eldre har sex og seksuell lyst. 
Forskningen viser også at seksuell helse bare i liten grad tas opp i forbindelse med oppfølging av sykdom og behandling (6).

\section{Språket er begrenset}

Begrepet «seksualitet» definerer en personlighetsdimensjon og ikke bare menneskets erotiske kapasitet. Åpenhet og kunnskap om seksualitet er nødvendig for å bedre den seksuelle helsen.

Språket vårt er begrenset når det gjelder sex og seksualitet. Vi kan beskrive seksuelle handlinger som onanering og samleie, og seksuell atferd som kos, flørting, å kle seg utfordrende eller å ha stevnemøter.

\section{«Språket vårt er begrenset når det gjelder sex og seksualitet.»}

Vi kan dele sex inn etter formål som å få barn, være en fornøyelse og en nytelse eller et uttrykk for en dypere kjærlighet til en partner. Og vi kan snakke om sex som berører temaene uønsket graviditet og abort, kjønnssykdommer, sikrere sex, seksuell tiltrekning, kjønnsidentitet og seksuelle tenningsvariasjoner og mønstre.

Derimot er vi stort sett dårligere til å finne ord for hvordan vi har det, og for hvilke følelser som er knyttet til sex, intimitet, seksuelle plager, utfordringer og bekymringer. Noe som er en utfordring for et riktig og godt behandlingstilbud for seksuelle helseproblemer.

Seksualitet handler om nærhet - både fysisk, følelsesmessig og intellektuelt: om nytelse og generøsitet, lekenhet, ømhet og begjær, og om seksuell lyst. Om problemer - og om myter. 
Skal myter avvæpnes, for eksempel myten om at den vellykkede mannen må vise til et stort antall samleier og orgasmer samt den store penisen - myter ingen kjenner seg igjen i, og som bidrar til usikkerhet og dårlig selvfølelse - trengs det i tillegg til viten også åpenhet $\mathrm{og}$ ord for dette.

\section{Synet på seksualitet endres stadig}

Ved de aller fleste kroniske sykdommene og funksjonshemningene påvirkes den seksuelle helsen. Uten åpenhet og et språk for seksualitet, seksuelle følelser og problemer faller temaet seksuell helse lett bort, også innenfor rammen av en såkalt helhetlig behandling.

Dagens nordmenn har resten av verden tett på seg gjennom reiser, utenlandsopphold, innvandring og tilgang til nye tekniske måter å kommunisere med omverdenen på. Mulighetene for opplevelser, påvirkning og ideer om andre måter å leve på, også seksuelt, utvides. Det er ikke utenkelig at utvidelsen også vil bidra til nye syn på og holdninger til helse, samliv og seksualitet.

Seksualitet er på ulike måter til stede i det offentlige rommet: Reklame og porno viser overdrevent vellykkede kropper, medier forteller gjerne om overgrep og seksualisert vold. Den seksuelle helsen påvirkes ofte negativt, og sterke tabuer om seksualitet lever i beste velgående.

Åpenhet om seksuelle problemstillinger påvirkes av at både helsearbeidere og hjelpes $\varnothing$ kende sliter med å finne bekvemme og dekkende ord når de vil snakke om sex, kjønnsorganer og seksuell helse.

\section{Undervisningen må bli bedre}

Undervisning om seksuell helse er sparsomt i skolen. Unge vokser opp med kunnskap om dette viktige feltet som i stor grad er hentet fra den digitale verdenen. Og fra porno - nåtidens lettest tilgjengelige seksualopplyser. 
Porno som viser prestasjonspreget, ufølsom og teknisk sex og idealiserte bilder av den perfekte kroppen, de store brystene og penisene, høy samleiefrekvens og serieorgasmer. Fakta om at aktivitetene er regisserte og rolleinnehaverne ekstraordinære og plukket ut etter spesielle kriterier og kroppslige attributter, er mindre tilgjengelig.

Obligatorisk undervisning og pensum om seksualitet og seksuell helse er så å si fraværende i profesjonsstudiene ved universiteter og høyskoler.

\section{Åpenhet er fortsatt utfordrende for helsepersonell}

Det er vanskelig å snakke om sex og seksuell helse. Ikke bare i det daglige, men også når vi søker hjelp hos lege eller annet helsepersonell. Vi har sparsomt med ord: Helsepersonell sliter med å forstå, imøtekomme og legge til rette for at seksualitet kan tas inn i samtalene.

Helsepersonell har fortsatt utfordringer med å være åpne om temaet, og det trengs bedre holdninger til homofile. Sykepleiere, så vel som annet helsepersonell, må være klar over at, og handle som om, pasientene ikke alltid har en heteroseksuell orientering (2).

\section{«Det trengs bedre holdninger til homofile.»}

En sykepleier eller lege som har fått lite eller ingen undervisning om eller metodisk eller praktisk opplæring innen temaet seksualitet på studiet, kan vanskelig vite hvordan problemer med og spørsmål om seksuell helse kan møtes og håndteres. Evne, god vilje og kunnskap er heller ikke nok. Egne holdninger er avgjørende.

For at helsepersonellet skal kunne gi riktig og god hjelp, er det deres ansvar å få pasientenes seksuelle helseproblemer tydelig frem under konsultasjonen. 


\section{Dagens livsførsel stiller flere krav om forståelse}

Reising, innvandring og ny kommunikasjonsteknologi bidrar i dag til nye måter å leve på og nye samlivsformer. Det stiller ytterligere krav til helsearbeidere om kunnskap, forståelse og holdninger til seksualitet og seksuelle problemstillinger.

At eldre mennesker i dag er mer aktive, også seksuelt, og bevisst på sine egne rettigheter, stiller nye krav til helsepersonell om å endre stereotype holdninger.

Og det fordrer en forståelse for og utdanning innen seksuell helse som også inkluderer eldre og seksuelle minoriteters helse og rettigheter (6).

\section{Referanser}

1. Weston ME, Coleman E. Defining sexual health: a descriptive overview. Arch Sex Behav. 2004;33(3):18995 .

2. Aars H. Menns seksualitet. Oslo: Cappelen Damm Akademisk; 2011.

3. Træen B, Stigum H, Magnus P. Rapport fra seksualvaneunders $\emptyset$ kelsene i 1987, 1992, 1997 og 2002. Oslo: Folkehelseinstituttet; 2003.

4. Aasland MW. Barna og seksualiteten. Oslo: Cappelen Damm Akademisk; 2020.

5. Almås E, Benestad EEP. Kjønn i bevegelse. Oslo: Universitetsforlaget; 2017.

6. Schaller S, Traeen B, Kvalem IL. Barriers and facilitating factors in help-seeking: a qualitative study on how older adults experience talking about sexual issues with healthcare personnel. International Journal of Sexual Health. 2020;32(2):65-80. DOI:

$\underline{10.1080 / 19317611.2020 .1745348}$ 
